\title{
ICONICIDADE ENUNCIATIVA NO TELEJORNAL: UMA PROPOSTA DE ANÁLISE EM DUAS DIMENSÕES
}

\author{
ENUNCIATIVE ICONICITY ON THE NEWS: A PROPOSAL FOR ANALYSIS \\ IN TWO DIMENSIONS
}

\section{LA ICONICIDAD ENUNCIATIVA EN EL NOTICERO: UMA PROPUESTA DE ANÁLISIS EN DOS DIMENSIONES}

\author{
Fabiano Maggioni \\ Professor Doutor no Departamento \\ de Ciências da Comunicação na \\ Universidade Federal de Santa \\ Maria - UFSM \\ fabianomaggioni@yahoo.com.br
}

\section{Resumo}

Neste trabalho pretendo ensaiar uma forma analítica para imagens televisuais, no caso, as apresentações de telejornais. Meu objetivo é mostrar a formação de significados nas imagens pela sua dimensão plástica e o ordenamento dos sentidos no campo semântico. Considerando estas duas grandes dimensões de significado, lanço o olhar para a materialidade plástica da imagem tentando identificar uma estrutura icônica que, por sua vez, seja capaz de determinar a formação de sentidos, pelo elenco e ordenamento de elementos visuais que forma. Faço uso da Teoria da Imagem e da semiologia dos discursos sociais como bases conceituais para análise do texto visual. Creio que seja possível estabelecer uma análise dos sentidos, a partir da materialidade plástica da imagem, uma vez que seja operado um recorte e ordenamento dos elementos que formam a estrutura icônica da imagem.

Palavras-chave: Imagem. Plasticidade. Telejornal.

\begin{abstract}
In this article I intend to rehearse an analytical form for televisual images, in this case, the presentations of news. My goal is to show the construction of meanings in the images by their dimension plastic and the ordering of senses in the semantic field. Considering these two major dimensions of meaning, I direct the look for plastic materiality of the image, trying to identify an iconic structure that, in turn, be able to determine the formation of the senses, by the cast and spatial visual elements that form. I am using the Theory of Image and semiotics of social discourses as conceptual bases for the analysis of visual text. However, I believe it is possible to establish an analysis of the senses from the plastic materiality of the image, if it gets cut and ordering of the elements forming the iconic structure of the image.
\end{abstract}

Key words: Image. Plasticity. News.

\section{Resumen}

En este artículo me propongo ensayar una forma de análisis de las imágenes televisivas, en este caso, la presentación de los noticeros. Mi objetivo es mostrar la formación de imágenes 
por su significación plástica y el ordenamiento de los sentidos en el campo semántico. Teniendo en cuenta estas dos dimensiones principales de significado, miro para la materialidad plástica de la imagen intentando identificar una estructura icónica que, a su vez, es capaz de determinar la formación de direcciones, y ordenar la lista de elementos visuales que forman. Yo uso la teoría de la imagen y la semiótica de los discursos sociales como bases conceptuales para el análisis del texto visual. Creo que es posible establecer un análisis de los sentidos, de la materialidad plástica de la imagen, si se opera un corte y ordenamiento de los elementos que forman la estructura icónica de la imagen.

Palabras clave: Imagen. Plasticidad. Noticeros.

Esta obra está licenciada sob uma Licença Creative Commons

\section{INTRODUÇÃO}

Quero começar este trabalho com uma consideração de Diana Luz Pessoa de Barros quando ao referir-se à semântica discursiva, no momento em que a narrativa se veste de temas e figuras para criar efeitos de realidade. Diz ela que essa ação discursiva, do sujeito enunciativo para com a narrativa, garante "a relação entre mundo e discurso" (BARROS, 2002, p. 113).

Para mim é essencial tal relação, pois esta expõe o objetivo maior da produção de uma imagem, aproximar-se da realidade para assim estabelecer vínculos entre sujeitos (enunciador e enunciatário) num eixo complexo, o do olhar. Tal relação se dá na atualidade quando as culturas ocidentais são eminentemente visuais (OCHOA, 1986, p. 10) e a vivência humana se funda em uma iconosfera de saturação audiovisual (VILLAFAÑE; MÍNGUEZ, 2002, p. 17) promovida principalmente pelo desenvolvimento tecno-midiático, onde o ser somente conhece o outro por mediações simbólicas.

Neste trabalho procuro demonstrar a força dos elementos plásticos envolvidos na produção do sentido, da apresentação do telejornal. Acredito que o set de gravação do telejornal é composto de forma estratégica com o intuito de torná-lo um "oráculo icônico" onde cada notícia que por ali passa, reveste-se de valores que são dados pela plasticidade visual.

Entendo que a cor, a forma, as linhas, os pontos, as texturas, o espaço, entre outros elementos visuais, definem o rito de passagem da notícia, cobrindo-a com a personalidade do conjunto enunciativo daquele telejornal. Existem diversas formas de olhar para esta faceta da produção de sentido no telejornal, escolho o viés da Teoria da Imagem espanhola para 
desmembrar as "energias" que compõem a imagem, e tornam o televisual o espelho das realidades vividas num conjunto cultural.

Considerando a apresentação do telejornal como parte de uma narrativa maior, a telejornalística, compreendo que ele precisa ser analisado sob a luz dos discursos sociais, neste ponto verifico como efeitos de verdade são produzidos a partir do icônico, onde são cristalizados em temas e figuras.

O percurso de elaboração do real por uma linguagem é o único modo de o ser conhecer seu redor. As ideias e os juízos que este elabora ao entrar em contato com seu meio de vivência lhes dão pressupostos para que ajuste sua conduta e estabeleça seu modo de vida. Ochoa (1986, p. 9) resgata este pensamento de Durkheim e acrescenta que tais ideias do mundo e das coisas são como um véu, entre nós e o mundo, e que as ações, eventos, acontecimentos e objetos do mundo, para nós, são apenas construções representacionais, pois diz ele, não há fenômenos naturais em estado bruto, tudo é representado.

\section{DESENVOLVIMENTO}

A linguagem e outros sistemas representacionais são fios que tecem uma rede simbólica, fruto da experiência humana, e nos ligam com a realidade. $\mathrm{Na}$ imagem, este simbólico é tecido por um ferramental de elementos morfológicos, dinâmicos e escalares que, como afirma Gadamer (1997), a tornam capaz de buscar um original-real, emanar suas características, pois "é somente a partir da imagem que o representado ganha plasticidade" (GADAMER, 1997, p. 202). Pois a imagem em seu caráter ontológico está lá para operar uma lembrança e constituir uma realidade, essa operação é essencialmente plástica, fundamentada em uma objetividade material.

A imagem, assim como qualquer fenômeno de expressão, é linguagem que, montada em estratégias de signos, propõe comunicar. Neste sentido, é possível elaborar uma estrutura de significação da imagem em dois polos, conforme demonstrado no Quadro 1.

\begin{tabular}{|l|l|}
\hline \multicolumn{1}{|c|}{ Significações Plásticas } & \multicolumn{1}{|c|}{ Significações Semânticas } \\
\hline $\begin{array}{l}\text { Materialidade compositiva da imagem em } \\
\text { seus elementos icônicos. }\end{array}$ & $\begin{array}{l}\text { Efeitos produzidos pela iconicidade que } \\
\text { remetem à cultura pela aproximação do real } \\
\text { que promovem. }\end{array}$ \\
\hline
\end{tabular}

Quadro 1 - Estrutura de significação da imagem

Fonte: Elaborado pelo autor com base em Villafañe (2000). 
As estruturas compositivas da imagem diferem das da linguagem verbal, pois a lógica em questão é a do ícone, muito mais furtiva e mutante, pela variabilidade que assume em elementos como cor, forma, textura, espacialidade, entre outros. Uma imagem também é apreendida de uma vez só no momento da leitura (percepção), e não de forma sequencial e linear. Se na produção de uma imagem, um processo complexo é desenvolvido para que o real possa ali ser recordado, na sua fruição o sentido parece revelar-se de forma instantânea.

De tal modo que, se é possível identificar em uma imagem uma similitude entre representação e representado, é possível também assimilar este processo como uma faculdade de linguagem. Assim, ao ler uma imagem, o ser vai aperfeiçoando sua visão, coletando elementos externos que enriquecem seu histórico cultural e o ajudam a elaborar uma memória de valores que ditarão preceitos para as futuras representações do que ele virá a ver.

Ochoa (1986, p. 16) quando pleiteia a eleição de uma semiótica específica dos fenômenos icônicos, afirma que a visão humana desenvolve-se junto com as formas de representação, sendo que estas sempre são culturais, e que a leitura do visual baseia-se em convenções históricas e socialmente variáveis. Dessa forma, conclui que os textos icônicos constituem códigos. Ou seja, o homem historicamente desenvolveu métodos para "desenhar" o real baseado em convenções culturais, estas são frutos de suas experiências sociais. Montou assim um arcabouço de códigos para uma linguagem. Um excelente exemplo destas "convenções de representação gráfica" é a perspectiva, estabelecida durante o Renascimento e que introduziu novas convenções em nossa visão das imagens.

Tais aspectos apontam particularidades da imagem, tomada como texto, de forma que é necessário entendê-la em sua composição plástica para podermos traçar um caminho no mínimo estável e compreensível até sua semântica e colocação em discurso. Assim, para montar um quadro das representações gráficas que nos permita identificar estruturas icônicas capazes de fazerem fluir discursos e produzir sentidos, é interessante analisar um pensador e mestre das artes que influenciou muitas das teorizações sobre a imagem, Wassily Kandinsky.

\subsection{As energias da imagem}

Pintor e professor da Bauhaus ${ }^{1}$ da primeira metade do século XX, Wassily Kandinsky encontrava já naquele tempo opiniões parecidas dentro da crítica das obras de arte. Afirmava

\footnotetext{
${ }^{1}$ Escola de design fundada em 1919 na Alemanha por Walter Gropius. Vanguardista no campo do design, arquitetura e artes, a Bauhaus inaugurou o estilo modernista e constituiu-se na primeira escola de design do mundo.
} 
ele que por volta da década de vinte daquele século, era muito corrente a opinião de que dissecar a arte pelo intuito da análise seria fazer uma autópsia que mataria a própria arte.

$\mathrm{Na}$ concepção de Kandinsky (2005, p. 10), tal pensamento "resulta da ignorante depreciação dos elementos postos a nu e de suas forças primárias”. O autor previa uma observação dos elementos da imagem e de sua ação primeira no conjunto compositivo da obra artística, a mim parece que queria deixá-los falar, expressar, e ver que capacidades tinham de formar sentidos.

Em seu conhecido livro "Ponto e linha sobre plano", Kandinsky trabalha elementos que considera básicos nas representações gráficas como os que dão título ao livro. A qualidade e ação dos mesmos na composição visual dá-se por meio de "energias" específicas da plasticidade que atuam por vetores. Dessa forma é possível perceber efeito de movimento em imagens fixas, por exemplo.

Entre os elementos da imagem, ponto, linha e plano, o autor postula que o ponto é introvertido, sendo a forma mais concisa e que nunca perde totalmente sua característica, mesmo que em sua forma exterior apresente ângulos. Plasticamente, as energias ${ }^{2}$ externas, vindas de todos os lados, que incidem sobre ele o tornam um elemento conciso.

O ponto sai de sua inércia no momento em que uma dessas energias externas, mais forte, o empurra rumo ao infinito criando assim uma sucessão de pontos que em sequência formam a linha. A Figura 1 apresenta uma ideia da primeira manifestação de energias no plano plástico.

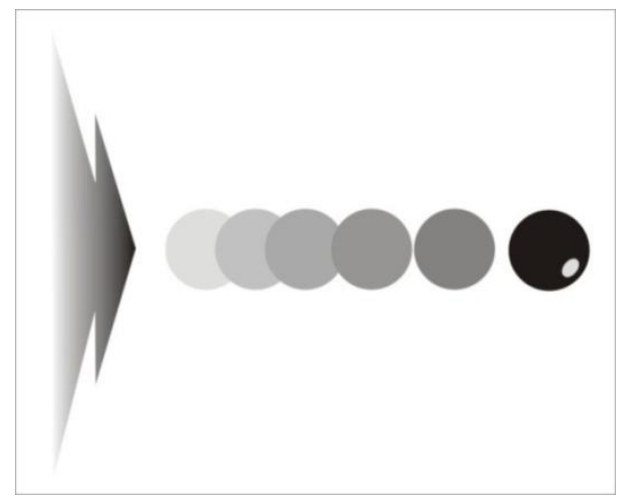

Figura 1 - Energia deslocando o ponto e formando a linha Fonte: Elaborado pelo autor.

\footnotetext{
${ }^{2}$ Kandinsky (2005) refere-se a forças resultantes de energias contidas no plano da representação e que, atuam em relação do plano com elementos da imagem, como ponto, linha e plano. São experiências psicológicas, análogas às forças físicas, de quem observa a imagem, explica Arnheim (2000). "Perceptiva e artisticamente, são absolutamente reais" (Arnheim, 2000, p. 10).
} 
Desta resultante da ação de forças externas sobre o ponto, tem-se então tensão e direção em uma linha reta realizáveis em quatro possibilidades: linha reta horizontal, que corresponde à superfície, que o autor considera como linha de apoio, onde o homem repousa, e sua ressonância é fria ${ }^{3}$ e de relação com o plano. A linha vertical que substitui o plano frio pela altura, quente, como considera Kandinsky (2005, p. 51).

Na linha diagonal o ângulo inclinado de forma igual às duas primeiras torna sua ressonância fria e quente, logo, sua energia como vetor é potencializada, expressando assim maior dinamicidade e força do que quando desenhada horizontal ou verticalmente. E ainda as linhas retas livres, que se situam no plano original ${ }^{4}$ sem uma regularidade e equilíbrio dentro do plano, estas linhas, são frouxas e pouco aderem ao plano original, como demonstrado na Figura 2.

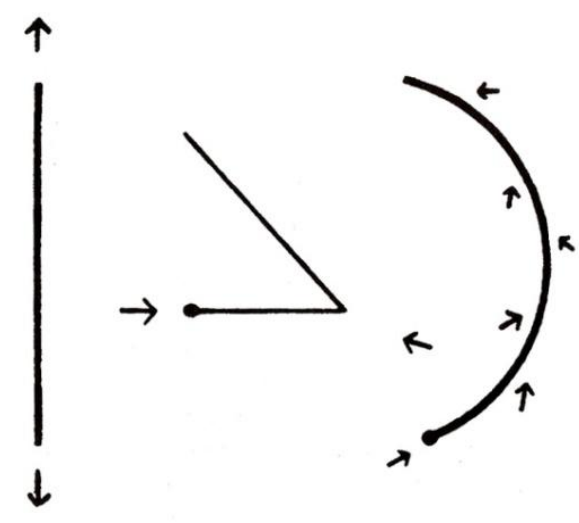

Figura 2 - Energias direcionadas sobre a linha Fonte: Kandinsky (2005, p. 71).

Quanto mais agudo o ângulo da linha, mais quente, quanto mais obtuso, afastando-se do ângulo reto, mais frio. Ao ponto que a linha vai tornando-se cada vez mais obtusa, ela vai perdendo sua força agressiva e seu calor até o momento de tornar-se círculo. O círculo é o lado passivo do ângulo obtuso onde a tensão é quase ausente (KANDINSKY, 2005, p. 64).

Desde o movimento adquirido pelo deslocamento do ponto, até o direcionamento vetorial das energias plásticas pela posição das linhas, Kandinsky chega ao plano plástico, primeiro ato da enunciação visual, lugar onde são determinados os limites para a expressão visual. O plano delimitador da imagem é o Plano Original, que determina um lugar, um espaço.

\footnotetext{
${ }^{3}$ Efeito de sentido relacional feito pelo autor e usado na pintura.

${ }^{4}$ É a superfície que comporta o conteúdo da imagem e seus domínios estão entre duas linhas horizontais e duas verticais. Também chamado de P.O., como tratam Villafañe (2000) e Kandinsky (2005).
} 
O plano que contém o tempo em que se desenvolve a narrativa visual, distribuídos pela perspectiva da imagem em primeiro e segundo plano, é o Plano Plástico. Sobrepondo espaços bidimensionais, o plano como elemento de imagem, induz ao efeito de terceira dimensão.

Voltando ao plano original, PO, Kandinsky (2005, p. 105) dá atenção especial a ele, pois ao considerar as propriedades fria e quente às linhas horizontais e verticais, respectivamente, trata o quadrado do plano como um elemento icônico sereno, objetivo e equilibrado. Ao predominarem dois tipos de linha, de altura e de largura, prevalece a ressonância objetiva do frio ou do quente. Linhas horizontais frias, verticais quentes. A posição das linhas no plano também produz uma ressonância na imagem. As linhas horizontais do quadrado podem ser altas ou baixas: as altas produzem ideias de maleabilidade, leveza, liberdade; as baixas, ideias de peso, densidade, coerção.

Já as linhas verticais podem ser de: direita, linhas que se movimentam para casa, denotam cansaço e vão em busca do repouso; linhas de esquerda, que assemelham-se às horizontais altas e denotam maleabilidade, leveza, libertação. Depois destas colocações acerca das quatro linhas que compõem o PO, Kandinsky (2005, p. 115) traçou uma quinta linha, a diagonal, atravessando o PO. Em um PO retangular esta linha diagonal aumenta ou diminui dependendo do ângulo, indicando assim tensão, conforme a Figura 3.
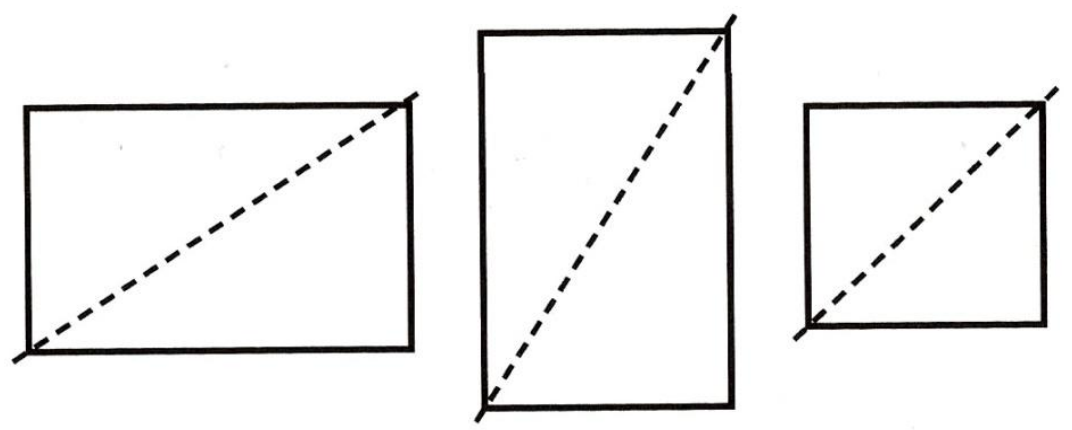

Figura 3 - A tensão do plano muda conforme a variação do ângulo da diagonal projetada Fonte: Kandinsky (2005, p. 115).

Desse modo, Kandinsky dá origem aos elementos fundamentais formadores da imagem. Interessante perceber que as tecnologias midiáticas aumentaram a oferta e complexificaram a estrutura das imagens, indo muito além de formas abreviadas e de imagens fixas, o movimento e as cores potencializaram a capacidade significante das imagens contemporâneas e convocaram um olhar mais aguçado às imagens televisuais. Das formulações de teorias que denotam elementos visuais de primeira ordem, me parece 
interessante a formada por Villafañe e Mínguez (2002), quando estes elaboram sua Teoria da Imagem em 13 elementos básicos, divididos em morfológicos, dinâmicos e escalares. Partem do ponto, linha e plano, mas adentram às nuances promovidas pela cor, exploram as noções de espaço e tempo, e vão até a força cinética das imagens em movimento.

A estrutura de elementos visuais formada pelos autores é demonstrada no Quadro 2:

\begin{tabular}{|l|l|}
\hline \multirow{5}{*}{ Elementos morfológicos } & Ponto \\
\cline { 2 - 2 } & Linha \\
\cline { 2 - 2 } & Plano \\
\cline { 2 - 2 } & Cor \\
\hline \multirow{5}{*}{ Elementos dinâmicos } & Forma \\
\cline { 2 - 2 } & Tensão \\
\cline { 2 - 2 } Elementos escalares & Ritmo \\
\hline \multirow{5}{*}{ Tamanto } \\
\cline { 2 - 2 } & Escala \\
\cline { 2 - 2 } & Proporção \\
\cline { 2 - 2 } & Formato \\
\hline
\end{tabular}

Quadro 2 - Elementos morfológicos, dinâmicos e escalares Fonte: Adaptado de Villafañe e Mínguez (2002).

A estrutura icônica da imagem começa a formar significados pela relação dos elementos básicos, chamados morfológicos. A partir deles o espaço e o tempo se formam dando características à composição. É possível que haja a predominância de certos elementos básicos, desta forma, a estrutura icônica será regulada por eles e sua identificação no enunciado será visível. No telejornal, elementos como a cor e a linha são notórios, por exemplo, aquela usada na forma de tonalidades, luminosidades, e esta, nos contornos e disposição dos elementos do cenário e sua relação com a posição dos apresentadores.

\subsection{Mídia e plasticidade visual}

Todos estes elementos formam esquemas icônicos que determinam os efeitos produzidos por certa narrativa televisual, como é o caso das apresentações telejornalísticas, 
onde a composição da imagem respeita alguns padrões icônicos no intuito de tornar preponderante certos valores centrais ao jornalismo. Quero recordar que este trabalho pretende expor as possibilidades de significação da imagem televisual, no caso de algumas apresentações de telejornais, elegendo a natureza icônica destas peças midiáticas e analisando-a como objeto científico de uma teoria de imagem.

Para conseguir montar uma estrutura icônica da imagem televisiva preciso, primeiramente, considerar dois atos psicofisiológicos da leitura da imagem, o perceptivo e o representativo. $\mathrm{O}$ primeiro seleciona a realidade e dela coleta estímulos que, agrupados em determinada ordem, elaboram um esquema pré-icônico do real. O segundo é a montagem do reflexo plástico do primeiro (VILLAFAÑE, 2000, p. 94), já estruturado e trabalhado em função de signos. Apesar de não ser possível separar material e cronologicamente os dois fenômenos, ao final deste percurso meramente ilustrativo teremos a representação da imagem por elementos plásticos envolvidos numa sintaxe.

A sintaxe visual é responsável por ordenar tais elementos, formando assim estruturas icônicas que, por sua vez, darão origem às significações da imagem. A significação plástica pode remeter diretamente a um referente, sendo chamada assim de normativa por Villafañe (2000, p. 164), ou adentrar a zona da abstração, sendo dessa forma, transgressiva. Ao que me interessa nesse trabalho, a apresentação do telejornal, creio que tendem a ser mais normativas, pois atendendo aos preceitos da credibilidade na informação e da proximidade com a realidade, o telejornal tende a fugir da transgressão da harmonia visual, em seus textos midiáticos.

Em sendo mais normativas, as composições da apresentação do telejornal também obedecerão à outra regra da percepção visual, a da simplicidade. Fato que pode ser observado nas próximas figuras, em que as performances dos apresentadores e a disposição dos elementos da composição criam ambientes de fácil assimilação e identidade com o enunciatário. Em outras palavras, é assegurar o enunciado visual com maior idoneidade da realidade. $\mathrm{Na}$ composição da imagem televisiva, o ordenamento visual é influenciado pelo ordenamento visual natural, aquele formado no fenômeno da percepção, e que faz o ser buscar coisas que lhe são afins.

Após compor um ordenamento dos elementos visuais, a imagem televisiva cria uma estrutura. Tal estrutura terá competência de mostrar predominância ou repetição de elementos visuais que, por sua vez, firmarão uma identidade visual. O elemento linha é um bom exemplo disso uma vez que está muito presente nos cenários de apresentação do telejornal, marcando espaços e ligando elementos da composição numa harmonia horizontal, 
favorecendo o conjunto das demais linguagens empenhadas neste tipo de narrativa. A seguir apresenta-se um exemplo de estrutura icônica na determinação da identidade visual formada, no caso, pelo elemento linha, conforme Figura 4.

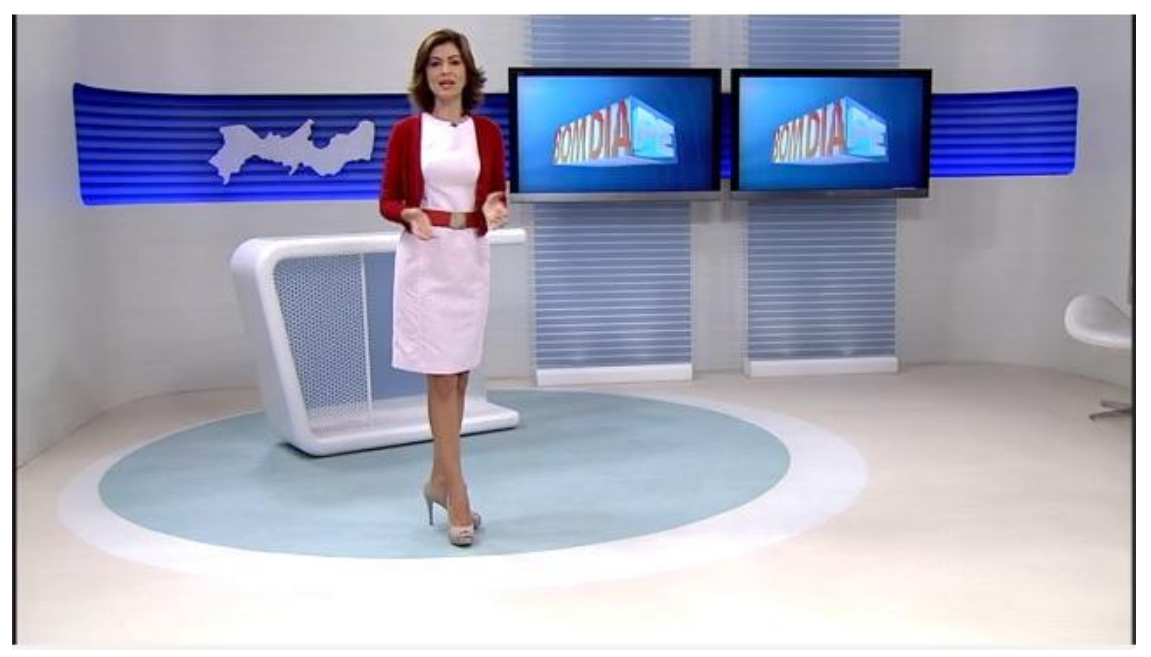

Figura 4 - Fragmento do telejornal "Bom Dia PE" em que a linha aparece normatizando a estrutura visual Fonte: Disponível em http://globotv.globo.com/rede-globo/bom-dia-pe/v/dependencia-quimica-e-assuntoabordado-no-bom-dia-pe/3130808/ (2014).

As linhas deitadas desenham no cenário as linhas de uma página pautada onde são escritas as notícias. Elas deslizam os olhos de quem assiste, no espaço, análogo ao que faz o texto escrito, sendo que o comprimento da linha relaciona-se a ideia de tempo e duração (KANDINSKY, 2005, p. 86). As linhas na delimitação do plano imprimem um tempo à imagem, nesse caso, mais longo e narrativo. As linhas retas horizontais mantém analogia à superfície onde o homem se movimenta (KANDINSKY, 2005, p. 50), ou seja, têm energia vetorial.

A distribuição das linhas na estrutura icônica desta cena, também garante à imagem um peso visual bem distribuído, onde há três colunas de linhas à direita e a apresentadora em pé, à esquerda do plano. Elementos de harmonia que tornam a imagem mais normativa, conveniente para este tipo de narrativa televisual.

Ao conseguir determinar uma ordem dos elementos visuais, enxergar uma estrutura icônica formada pelo ordenamento do espaço e tempo na imagem, é possível chegar à significação plástica. Villafañe (2000, p. 172) estabelece em sua Teoria da Imagem que o sentido de uma imagem é dado pela significação que sua plasticidade consegue montar, ou seja, uma imagem pode até carecer de sentido, mas nunca de significação plástica.

O sentido a que se refere está enunciado numa imagem e ligado a ideias estéticas, sociológicas, políticas, históricas, entre outras. Desta forma, o autor elabora o conceito de 
significação plástica como "a soma de todas as relações produzidas pelos elementos icônicos organizados em estruturas segundo um princípio de ordem, à margem do sentido de que, ocasionalmente, a imagem é portadora".

Se até aqui postulei um caminho que chegasse a formação da significação plástica, agora é necessário verificar como esta significação conclama sentidos em sua semântica. Desta forma, uma área de junção é formada na correspondência que há entre estrutura icônica e a lógica das ideias do tema de uma imagem. Trata-se da formação discursiva que uma imagem é capaz de produzir pela sua iconicidade. Para trabalhar essa conexão icônicodiscursiva, faço um aporte dos preceitos da semiótica dos discursos sociais na qual Barros (2005) mostra como o enunciador usa de artimanhas enunciativas para persuadir seu enunciatário, elaborando um texto visual com valores que montam temáticas carregadas de figurativizações do real.

\subsection{Os discursos da plasticidade}

A imagem constitui, no grande enunciado televisivo, o elemento material capaz de comunicar ao transpor sentidos desde o enunciador até o enunciatário. E como considera Verón (2013, p. 148), toda comunicação é mediada, em todos os seus níveis, uma vez que o sentido somente consegue circular se estiver materializado. A materialidade plástica está assentada na materialidade do dispositivo midiático, esta característica dá à imagem condições de existência por tornar concretos sentidos e fazer circular significações pelos grupos sociais. A identificação de tais sentidos no âmbito social se dá então, pela formação discursiva.

O nível de formação, circulação e consumo destes sentidos, no televisual, ocupa um espectro bastante amplo e para enxergar os sujeitos envolvidos neste processo e os discursos que comungam, é conveniente considerá-lo como enunciado. No enunciado da apresentação do telejornal, a posição do enunciatário é desenhada e prevista dentro do enunciado, pelo enunciador. Esta previsão é estratégica e visa dar ao enunciatário, elementos de valor que, por sua vez, lhe sejam caros e que, por conseguinte, o persuadam. Esse arranjo de valores é arquitetado no momento da produção da mensagem e, no campo das imagens, diz respeito às escolhas da formação icônica.

Esta relação enunciativa é chamada por Verón (2004, p. 217) de dispositivo de enunciação, nele, entidades discursivas (enunciador/enunciatário) determinam as modalidades do dizer. Os discursos televisuais, envolvidos no enunciado da apresentação telejornalística 
comportam, portanto, a imagem (lugar) de quem fala (enunciador), a imagem daquele a quem se destina o discurso (enunciatário) e a relação entre estes dois.

Para persuadir, valores são disseminados no discurso televisual na forma de temas e figuras, modo pelo qual conseguem recriar situações, personagens, lugares, objetos, ações, e outras tantas representações que remetem ao real do telespectador/enunciatário. Considerando a imagem como um texto montado pelo visual, nele há a possibilidade de identificar os papeis dos sujeitos enunciativos e suas competências em expandir valores dados pelo icônico, nos temas e figuras, na dimensão semântica da imagem.

A estas estratégias discursivas, Barros (2005, p. 66) chama de percurso temático e figurativo, onde os valores são disseminados em temas, revestidos de figuras e que, por sua vez, garantem ao discurso efeitos de realidade, tão caros ao telejornalismo. Um tema pode ser identificado numa imagem devido à recorrência de traços semânticos, dados pelos elementos icônicos, sendo que o percurso temático será sempre abstrato.

Em seguida, viriam as figurações discursivas para revestir os temas de conteúdo com sensorialidade (BARROS, 2005, p. 69), porém, diferente de um texto verbal, a imagem é essencialmente figurativa, ao ponto de Barros (2002, p. 117) chamar de iconização, o revestimento exaustivo dos temas por figuras para forçar o apelo referencial. Com temas e figuras, o texto visual aproxima-se da realidade, pois eles são níveis de concretização dos sentidos (Fiorin, 2000, p. 64) onde os temas organizam elementos do real e as figuras criam um simulacro da realidade.

Dessa forma, temos elementos da plasticidade que, elencados em uma composição formam uma estrutura icônica que, por sua vez, traçam um percurso temático e figurativo no discurso televisual. Vejamos três recortes da chamada de um telejornal. Escolhi uma chamada de jornal por ser mais sucinta e sintetizar a identidade visual do telejornal que está anunciando, como mostra a Figura 5. 


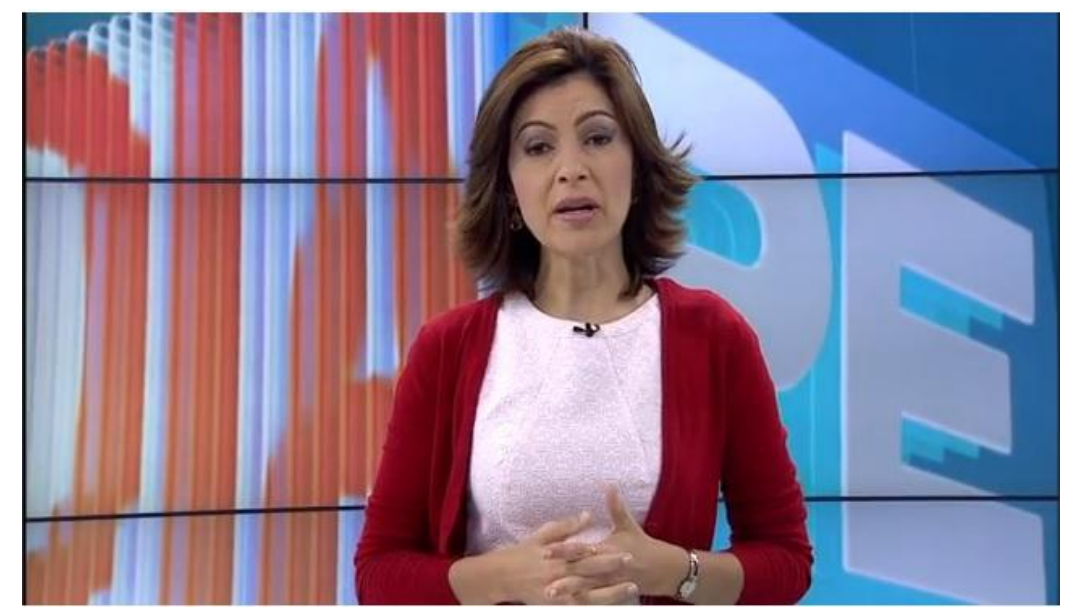

Figura 5 - Temática “drogas" - estrutura icônica mais pesada

Fonte: Disponível em http://globotv.globo.com/rede-globo/bom-dia-pe/v/dependencia-quimica-e-assuntoabordado-no-bom-dia-pe/3130808/ (2014).

Quando a apresentadora começa a chamada, traz uma temática forte, “drogas”: “- Olá! No Bom Dia Pernambuco desta sexta-feira tem um assunto que é um drama para muitas famílias. Mexe com pais, mães e filhos. É o consumo de drogas." Em seguida, a apresentadora exibe uma nota coberta com imagens de jovens se drogando. Toda temática deste fragmento é revestida de elementos icônicos, alguns já descritos, que possibilitam a apresentadora dar "importância" para o assunto.

O texto verbal também tem sua figura, pois a droga "mexe" com pais, mães e filhos, e esta figura é potencializada pelo uso correto do enquadramento e do peso visual que as linhas naquele momento, compõem. O plano da câmera é mais fechado, elevando a dramaticidade da cena. Esta aproximação também expõe as linhas do cenário, tanto do recorte dos vídeos quanto dos caracteres ao fundo. Elementos que inserem tensividade no plano icônico.

O tom cinético dado pela horizontalidade das linhas cria um ambiente de transitoriedade, lugar por onde tudo que é de interesse passa. Quer dizer, ambiente perfeito para o elenco das notícias que merecem destaque. A passagem para outra temática nas informações da apresentadora também aponta para a escolha de outros enquadramentos, mais narrativos e abertos. Tanto que, em seguida, a cena fica mais equilibrada, com plano enquadrado um pouco abaixo da cintura, e o assunto é sobre as festividades locais. No último plano, todo aberto, demonstrado pela Figura 6, a temática é esportes. 

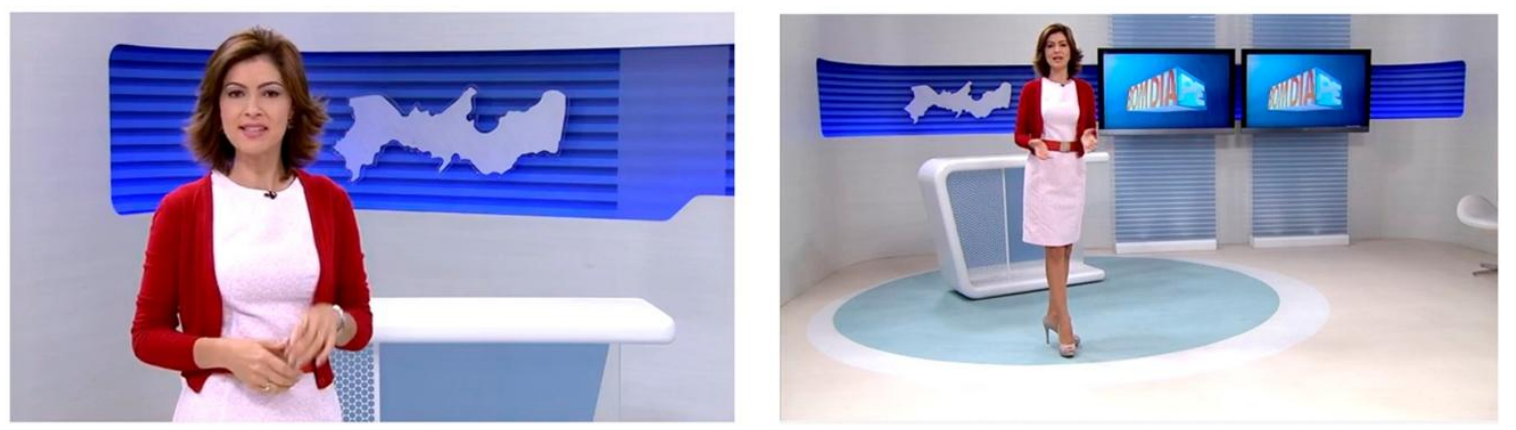

Figura 6 - Sequência com a temática "festividades e esportes". Estrutura icônica mais harmônica e fluída Fonte: Disponível em http://globotv.globo.com/rede-globo/bom-dia-pe/v/dependencia-quimica-e-assuntoabordado-no-bom-dia-pe/3130808/ (2014).

A locução da sequência demonstra o novo tom: “- Veja ainda como participar do show da esperança. Você já pode comprar a camisa! Neste fim de semana tem o baile dos artistas no Recife. Confira as novidades com a gente! No futebol, os lances da noite nos jogos de Náutico e Esporte, pelo Nordestão. Essas e outras notícias às seis e meia da manhã. Até lá!”

A troca de planos vai tirando o tom dramático e dando narratividade ao texto visual, auxiliando assim, a significação do texto verbal. As linhas do cenário, e seu uso, compõem uma estrutura icônica onde sua presença é facilmente percebida. Levando em conta a capacidade de espalhar energia plástica pelo plano, dar movimento à imagem e direcionar a leitura de quem olha (VILLAFAÑE, 2000, p. 103), nesse caso, a linha é protagonista da estrutura icônica. É a figura das temáticas seguintes, onde ajuda a "ventilar" os fatos pelo enunciado.

Vejamos também que o ambiente criado pelo telejornal evita conflitos visuais. Há um ordenamento visual que facilita a identificação, pelo enunciatário, de um lugar agradável, bom para "repousar" o olhar.

Nesta amostra analítica busco identificar os principais elementos que compõem a estrutura icônica, para deles extrair significados plásticos. Ainda existem influências fortes de elementos como a cor e a textura que poderiam ser explorados em um outro momento.

Outro ponto a ser observado é que os efeitos de figuratividade, no texto visual, não só revestem a temática, como são praticamente a essência deste tipo de linguagem. Portanto, a iconicidade (plástica) é diretamente ligada à figuratividade (semântica), onde a cor vermelha, por exemplo, pode ser tomada como figura de ação, durante o anúncio de uma matéria policial. 


\section{CONSIDERAÇÕES}

Longe de esgotar as possibilidades de significação de uma imagem, tento traçar um percurso que possa mostrar, com determinada lógica, as potencialidades icônicas das mesmas. Como postulava Ochoa (1986, p. 16), a iconicidade merece ser pesquisada por estar diretamente relacionada à capacidade do homem de desenvolver sua história por formas de representação cultural, expressas por códigos icônicos.

Se existem códigos, formula o autor, eles merecem ser verificados pela forma como se caracterizam. É dizer, verificar se uma imagem está em correlação com seu conteúdo assim como um enunciado linguístico em relação com seu sentido. Pesquisar o icônico é um desafio científico uma vez que o fenômeno da imagem está diretamente ligado à realidade. Tanto que, por ser um fenômeno tão cotidiano, não parece requisitar maiores questionamentos conceituais. No entanto, lembram Villafañe e Mínguez (2002, p. 17), é necessário conhecer sua natureza e sua grande diversidade de manifestações para ir além da simples constatação da sua manifestação.

Os próximos passos da pesquisa, da qual este trabalho é um prospecto, apontam para a identificação e delimitação de esquemas icônicos que sustentam as demais linguagens envolvidas no televisual, produtoras de sentido. Neste caminho existem indicativos recorrentes encontrados no objeto empírico, refiro-me a insistente busca pelo equilíbrio visual e a forma icônica normativa, realística, como aspectos dominantes deste tipo de narrativa. Estes aspectos parecem espelhar melhor os valores de vida de quem assiste as notícias favorecendo assim a busca pelo valor de credibilidade do programa.

A amplitude das dimensões envolvidas no fenômeno icônico pode explicar a quantidade de teorias que tentam aproximar-se dele, para explicá-lo. No entanto, para localizar a imagem num cercamento científico, é preciso identificar nela o que lhe é essencial e específico. Segundo Villafañe e Mínguez (2002, p. 23), é sua natureza icônica.

\section{REFERÊNCIAS}

ARNHEIM, Rudolf. Arte e percepção visual: uma psicologia da visão criadora. São Paulo: Pioneira, 2000.

BARROS, Diana Luz Pessoa de. Teoria do Discurso: Fundamentos semióticos. São Paulo: Humanitas, 2002.

BARROS, Diana Luz Pessoa de. Teoria semiótica do texto. São Paulo: Ática, 2005. 
FIORIN, José Luiz. Elementos de análise do discurso. São Paulo: Contexto, 2000.

GADAMER, Hans-Georg. Verdade e Método I: traços fundamentais de uma hermenêutica filosófica. Petrópolis, RJ: Vozes, 1997.

KANDINSKY, Wassily. Ponto e linha sobre o plano. São Paulo: Martins Fontes, 2005.

OCHOA, Cesar Gonzalez. Imagen y sentido: elementos para una semiotica de los mensajes visuales. México: UNAM, 1986.

VERÓN, Eliseo. Fragmentos de um tecido. São Leopoldo: Unisinos, 2004.

VERÓN, Eliseo. La semiosis social, 2: ideas, momentos, interpretantes. Ciudad Autónoma de Buenos Aires: Paidós, 2013.

VILLAFAÑE, Justo. Introducción a la teoria de la imagen. Madrid: Pirámide, 2000.

VILLAFAÑE, Justo; MÍNGUEZ, Norberto. Principios de teoria general de la imagen. Madrid: Pirámide, 2002.

Original recebido em: 18/09/2014

Aceito para publicação em: 03/08/2015

Fabiano Maggioni Doutor em comunicação pela Universidade Federal de Santa Maria e Professor Adjunto do Curso de Publicidade e Propaganda da UFSM. Estuda imagem e processos de significação aplicada à produção gráfica $\mathrm{e}$ televisualidades e participa de grupos de pesquisa com interesses afins. 